companied by his graduate students. He was also a fan of Indiana University basketball and football. John was a competitive soul and loved a good game of tennis. When he could no longer play, he transferred his competitive urges to a good game of cribbage.

John Lovell is survived by his wife, Joanne Granger Lovell of Bloomington, Indiana; his daughter, Sara Lovell Britton of Chicago, Illinois; his son, David Lovell of Indianapolis, Indiana; and his brother, William Lovell of Colorado Springs, Colorado. Memorial contributions may be made to a scholarship fund established in his name through the Indiana University Foundation.

The obituary published in Madison's newspaper, the Wisconsin State Journal, accurately sums up the emotions that many of us felt upon hearing of his passing: "Throughout his life and academic career, generations have found in John a good friend, a wise counselor, and a kind soul."

\section{Warren E. Miller}

As noted in the previous issue of $P S$, Warren E. Miller died on January 30, 1999, in Scottsdale, Arizona, from complications associated with his long battle against diabetes. Beginning with The American Voter (1960, coauthored with Angus Campbell, Philip Converse, and Donald Stokes), Miller's books and articles have had a pervasive impact on the development of contemporary research on electoral behavior and public opinion in several other countries as well as the United States. In addition to his own research and publications, however, Miller's widespread influence on contemporary political research is based on his unique role in leading several major institutions that continue to support a wide variety of other social scientists. In particular, Miller created the Inter-university Consortium for Political and Social Research (ICPSR), the University of Michigan's Center for Political Studies (CPS), and the National Elections Studies (NES), and served as president of the American Political Science Association.
Miller was born and raised in South Dakota and served in World War II before attending the University of Oregon, where he earned both his B.A. and master's degrees. Those who recall Miller's subsequent leadership in creating an archive of roll call data for the U.S. House of Representatives and Senate may be interested to learn that his master's thesis explored methods for analyzing such individual-level data, in order to produce separate scales for each apparent "dimension."

After Oregon, Miller entered the doctoral program at Syracuse University, but he also joined Angus Campbell's staff at the University of Michigan's young Survey Research Center to carry out the first comprehensive national survey concerning a presidential election. With that project, Miller began an extraordinary career of service to our profession, for he served as study director, principal investigator, or center director for every national election survey from 1952 through 1992. Miller's own doctoral dissertation was based on the 1952 Michigan survey, and was primarily devoted to "issue-oriented voting." As with his earlier work on roll call data, that aspect of Miller's dissertation anticipated another continuing research objective of many political scientists: the extent to which citizens' preferences concerning policy-related controversies play some role in shaping their electoral choices for president or congressperson.

\section{Initial Publications and Leadership}

Miller's dissertation research also contributed to the Center's major report on the 1952 Michigan survey, The Voter Decides (1954, coauthored with Angus Campbell and Gerald Gurin). After that project, Miller became an assistant professor of political science at the University of California, Berkeley. His correspondence from that period reveals some frustration with the lack of comparable facilities for quantitative research outside the Michigan Survey Research Center, and he returned to Ann Arbor when Campbell obtained funding for another major survey concerning the 1956 election. During that period, Miller and Campbell were joined by Converse and Stokes in preparing a major report on voting behavior in presidential elections: The American Voter (1960).

The scope and conclusions of The American Voter are difficult to summarize briefly in this context, as is the enormous research literature that has been stimulated by that book. Miller and his colleagues presented a general explanatory framework for understanding how citizens come to their individual decisions concerning participation (or turnout) in national elections and voters' eventual choices between the major party candidates. Particular emphasis was placed on voters' continuing identifications with one or the other major political party as a remarkably stable predisposition that shapes a variety of other political attitudes as well as vote choice. The authors' explanatory framework, however, incorporated a wide variety of other factors, including "nonpolitical" attributes such as social or economic characteristics (whether or not they are associated with any "group influence") and voters' apparent opinions about current "issues" and "ideological" concepts, as well as the personal qualities of the candidates. Several generations of scholars have made their reputations by criticizing or extending the statistical analyses or substantive conclusions in The American Voter, and its influence quickly spread to several other countries.

\section{The Inter-university Consortium for Political and Social Research}

Modern social scientists routinely expect that quantitative data used in influential publications will be generally available for secondary analysis by other scholars, but that kind of open access did not always exist. Traditionally, quantitative data was usually seen as a private resource for the scholar or institution that collected it, and such materials that were "available" were often difficult to understand and use. Even before the publication of The American Voter, many other scholars had participated in seminars concerning the 
new Michigan election surveys, and were eager to carry out their own analyses of the same data. Miller and his colleagues made those machine-readable (not yet computerbased) data and documentation available to colleagues at other institutions, and they recommended that other large research projects follow the same practice. The data from the early election studies, however, were not prepared for outside users, and the small staff in Ann Arbor W is overwhelmed by requests for assistance from researchers who wanted to use those materials.

In that context, Miller created the Inter-university Consortium for Political Research in 1962, based on a series of bilateral agreements between the Political Behavior Program at Michigan's Survey Research Center and research organizations or academic departments at other universities. The original objectives of that initiative were fairly modest in comparisun with the scope of current Consortium activities and membership. Staff members in that first year were told that the Consortium would be successful if as many as twenty other universities became continuing members, so that their annual fees covered the costs of helping scholars use the election surveys and a small number of other well-known studies.

Within a year, however, it became clear that Miller's general goals of broad access to quantitative data and assistance to potential users were extremely well received within the academic community, and membership in the Consortium simply to k off. With his coauthors from The American Voter, Miller combined the Consortium's growing archive of survey data with a popular summer program in quantitative methods, and began to develop an archive of historical materials based on aggregate election returns and Census data. Based on that combination of activities, the initial small group of cooperating universities quickly grew to several dozen, then a hundred, then several hundred, on its way toward the current international and interdisciplinary organization. In 1970, Miller stepped down as the executive drector of the Con- sortium in order to lead the new Center for Political Studies, which included the Consortium, the American election surveys, and a variety of other projects directed by colleagues at Michigan and elsewhere. In subsequent years, however, Miller maintained a strong commitment to the Consortium and its services, and he was an associate drector of that organization until his death.

The early success of the Consortium was substantially based on Warren Miller's unique approach to other social scientists, a quality that was also evident in his subsequent development of the National Election Studies. Throughout his career, Miller was seen as an ally or partner by an astonishing number of researchers. This pattern was evident from the first meetings of official representatives from the Consortium's member organizations and continued with an elected Council when the membership became too large for group discussions. To staff members (like myself) in that young organization, it was clear that most of those representatives from other universities were already colleagues of Miller's, based on a variety of shared research objectives.

It was also clear that many of the Consortium's relationships with other universities were the result of repeated communications and personal visits by Miller to those campuses. Through continuing correspondence and travel on a scale that will almost certainly not be repeated, Miller developed cooperative relationships with colleagues in a very large number of colleges and universities. The early Consortium was primarily built on those relationships, and all of the Consortium's projects were designed to maximize the scope of participation and collaboration within those institutions, on a national and international basis.

\section{Extending the Scope of Political Research}

While the Consortium membership was growing, Miller and his colleagues entered into a series of collaborative projects that would substantially expand the research agenda for all of the institutions in- volved. In particular, election studies were developed with colleagues in Canada, Sweden, Finland, Norway, Germany, the Netherlands, Australia, and Japan, in addition to Stokes' collaboration with David Butler in Britain and Converse's work in France.

Miller and his colleagues devoted much of their time in the 1960s to collaboration with electoral scholars in other countries, but they also completed several influential essays concerning the implications of statistical results based on surveys of individual citizens for the behavior of elected officials, or for the political system as a whole. Several of these essays concerning the relationships between ordinary citizens and political leaders or institutions were combined in Elections and the Political Order (1966), the final publication coauthored by all four authors of The American Voter.

\section{Creation of the American National Election Studies (NES)}

As discussed above, the early years of the Consortium were an intensely collaborative and cooperative venture. As its creator, Warren Miller specialized in bringing together scholars with different perspectives and objectives, and in creating projects (and funding) that made it possible for a variety of participants to benefit from a common set of research or technical objectives. In the 1970s, Miller used the same general approach in order to broaden the scope of scholarly participation in-and obtain continuing support for-the series of U.S. election surveys that began in 1952. The key to this new venture, which was quickly called the National Election Studies (NES), was the development of widespread support for a common design and a comprehensive set of measurement objectives that could support the broadest possible range of analytic objectives. This desire for broader participation and innovation, however, had to contend with a second major objective for this new enterprise: to preserve continuity and analytic comparability between new election studies and all 
of the previous surveys in that series.

Within the electoral field, comprehensive agreement of that sort is very difficult to achieve, and even harder to maintain over several different elections. In developing the initial NES grant from the National Science Foundation, Miller used his extensive relationships throughout the electoral community, as well as the initial Board of Overseers, in order to build support within the electoral community for a research agenda that would support a substantially broader group of potential analysts. To reach that objective, Miller had to deal with a variety of conflicts within the electoral community, including alternative approaches to electoral explanation and change over time, as well competing ideas about the nature of public opinion and different approaches to measurement. Most of those conflicts have now been faced by several generations of Board members in developing NES surveys from 1978 through 1998, and they seem likely to persist for quite some time, along with Miller's general approach to disagreement between scholars within the electoral community.

\section{Leadership of the American Political Science Association}

During the same period that he developed the National Election Studies, Miller was elected president of the American Political Science Association. He was closely associated with Evron Kirkpatrick, the long-term executive director of the Association, and he led the search for Kirkpatrick's replacement, Thomas Mann. Before and after his term as president, Miller was active on several Association committees and a variety of initiatives to strengthen the professional staff of the Association and its services to individual members, as well as the resources available to support political research.

\section{Recent and Current Research}

In addition to his organizational or institutional activities, Miller was an active and productive scholar throughout his career. In 1976, he published Leadership and Change: Presidential Elections from 1952-1976 (with Teresa Levitin), which explored the electoral role of the new issues and greater emphasis on "liberal vs. conservative" orientations that characterized American electoral politics during the late $1960 \mathrm{~s}$ and 1970s. During the same period, he began a series of projects with Kent Jennings based on surveys of delegates to the Democratic and Republican nominating conventions. Their analyses featured comparisons of the policy-related preferences of such activists within the two major parties with the same kinds of preferences of ordinary citizens, and led to Parties in Transition: A Longitudinal Study of Party Elites (1986, with Jennings).

One summary of Miller's many intellectual contributions should be mentioned in this context. In the early 1990 s, several of Warren's colleagues participated in a festschrift for him, which resulted in Elections at Home and Abroad: Essays in Honor of Warren Miller (1994, edited by Jennings and Tom Mann). The first chapter of that book (also written by Jennings and Mann) reviews the many ways in which Miller's own research has influenced election studies in the United States and several other countries, including his work on the relationships between voters' attitudes and preferences and actions of their elected representatives.

In 1980, Miller moved to Arizona State University, along with his wife, Professor Ruth Jones. Although he was no longer on the faculty at the University of Michigan, Miller continued as principal investigator of the National Election Studies through the rest of that decade. During that period, he also entered into a collaborative relationship with this author of this summary, an effort that led to a series of essays in the British Journal of Political Science on the U.S. presidential elections of 1980, 1984, and 1988, and which culminated in the publication of The New American Voter in 1996. In preparing that book, Miller and I intended to reopen many of the de- scriptive and explanatory questions that were emphasized in the original treatment of the "American Voter," and to emphasize several issues that we believed must be addressed in any continuing effort to understand the choices made by the U.S. electorate.

Despite his illness, Miller continued to be productive in the last year of his life. Shortly before his death, he was notified that his paper on "The Other Dimension: Dynamic Constraint in American Political Public Opinion" had been accepted by Political Analysis, and he had recently completed his editing for a forthcoming book on representation with colleagues from France, Norway, Finland, Germany, and the Netherlands. This spring, Miller and I were working on an essay on the 1996 presidential election, a paper that will be presented at this year's APSA meetings.

Since the 1950s, Warren Miller had an enormous impact on the ideas and objectives, as well as the lives and careers, of a large number of social scientists. Miller's own publications played a major role in shaping the research agenda for several generations of scholars, but his influence was also based on his unique ability to identify common purposes among colleagues with quite different perspectives, so that complex projects could succeed. In effect, Warren Miller specialized in making it possible for other scholars to carry out their research, and he created two major institutions that transformed important aspects of social science research. The results of those efforts can be seen in substantial portions of our current literature on voting and elections, as well the continuing success of the institutions he led.

As Miller's partner in one aspect of his work since 1981, it was always clear that I had a great deal of company. Over the years, many political scientists continued to ask for Miller's advice concerning their own work, or for his assistance in initiating new projects or returning to unfinished tasks. Like me, a substantial number of people will miss him as a long-standing colleague and ally, as well as a friend. I find it hard to 
imagine that anyone else in academic life will again have that kind of influence on the lives and careers of so many people.

J. Merrill Shanks

University of California, Berkeley

\section{Good-Bye to Two Dear Friends: Warren Miller and Dwaine Marvick A Personal Memoir}

They left us within the short span of four weeks - Warren in late January, Dwaine in late February. I met both of them almost half a century ago, in the early 1950 s, and also within the span of four weeks. The person who brought us together was the sociologist Morris Janowitz, a friend with whom I had worked in a government agency during the early years of the war and whom I would visit from time to time in Ann Arbor. Janowitz had been working with Miller on a critique of Lazarsfeld's "Index of Political Predispositions" in the Erie County Study, and he was collaborating with Marvick on a restudy of the Survey Research Center's 1952 presidential election data that was more sociologically oriented than the original, more psychologically inspired SRC report. Miller, still working on his Ph.D. with the social psychologist Floyd Allport at Syracuse, had come to the SRC as an associate study director of the 1952 study, and Marvick, just out of Columbia with his Ph.D., was a Carnegie Fellow at the Center. A fourth person in what became a kind of unholy foursome in the eyes of Jim Pollock, chairman of Michigan's then-hide-bound department, was Sam Eldersveld, the only contemporary behavior-oriented Michigan Ph.D. who was an assistant professor. In due time, Janowitz, Eldersveld, and I would publish a reader in political behavior, Miller and Marvick having gone off to California-Warren to Berkeley from where he returned in 1956 to run that year's SRC election study; Marvick to Los Angeles where be took deep Western roots, not an easy thing for his brilliant wife, Elizabeth Wirth Marvick, who had grown up in Chicago as the daughter of the urban sociologist Louis Wirth.

Over the years, Warren and I grew close, not so much as researchers, but as promoters and organizers of a number of professional undertakings. Dwaine and Sam Eldersveld grew close as they collaborated in a more scholarly vein on many studies of party elites in Europe and Asia. Nevertheless, the paths of this foursome crossed often in the fifties and sixties. I worked closely with Dwaine on a number of projects, including our joint editing of a volume on elites for a series of behavioral research studies published by the Free Press of Glencoe whose gutsy owner, publisher, and editor, Jerry Kaplan, had shown up in Ann Arbor during the 1954 Research Seminar on Political Behavior, precursor of what later became the summer training program of the Inter-University Consortium for Political Research (ICPSR's original name). Dwaine, Warren, and I saw each other a good deal during the early years of the ICPR. Warren was still the executive director, Dwaine chaired the organization's council in 1966-67, and I was invariably around in one role or another. During the years when our Ann Arbor visits overlapped, we invariably dined the first evening at Eldersveld's and spent the late evenings at Warren's. Janowitz had gone off to Chicago by that time and we saw little of him until years later when Dwaine, Jerry Kaplan, and I participated in a two-day conference held in Morris' honor after Parkinson's Disease compelled him to retire from the University of Chicago.

Warren and Dwaine were quite different persons, with quite different qualities, and I don't mean the obvious ones like Warren was a natural promoter, organizer, and administrator, and Dwaine much preferred playing the role of the learned and intellectually wide-ranging professor. To contrast these qualities would give an altogether false and unnecessarily gratuitous picture of either one of them. I also knew Warren as the most meticulous analyst and insightful interpreter of electoral data. My earliest image of him is swinging in his office chair, sharpened red pencil in one hand and slide rule in the other (to figure out percentages), literally lost in the piles of hand-written analysis sheets of data taken off the countersorter whose counting device, permitting cross-tabs, looked like an old-fashioned telephone switchboard with four colored lines-red, green, blue, and (I think) yellow. He was totally devoted to his work as one of the country's most informed and level-headed electoral scholars. Given his collaboration with brilliant colleagues, his contribution to the Michigan "paradigm" is sometimes belittled, but his last major work, with Merrill Shanks, belies this misunderstanding of his contributions. And so does the unpublished draft of the "representation study" of which only a small part ever saw the light of day. Conversations with Warren, if not concerned with the politics and management of the organizations which, he felt, are needed to make our discipline strong and respectable, centered on electoral research. For Dwaine, on the other hand, a broad knowledge and understanding of what was going on in all of the social sciences was a major interest. We would talk about Freud and Mannheim and Durkheirn and Weber and Boas and Simmel and, more often than not, his friend, the sociologist Ed Shils or the political psychologist Nathan Leites and, last but not least, our mutual friend, Harold Lasswell. His conversational style was light and fast moving, and our talks often included Liz, a learned political psychologist in her own right. Dwaine was as broad and ecumenical a scholar as Warren was a specialized and topic-tropic investigator. This is not to say that Dwaine was not an equally proficient analyst. His publications revealed the same great care in data handling and interpretation as Warren's.

Now that he is gone, I can only say "thank you, thank you" to Warren for teaching me what rigorous quantitative data analysis is all about. And in that role, he was a master and unequaled mentor, not only for me but for generations of colleagues and students. I remember so well the two or three morning 